\title{
Strip casting using a roll caster equipped with a scraper
}

\author{
Toshio Haga ${ }^{1, *}$ \\ ${ }^{1}$ Osaka Institute of Technology, Department of Mechanical Engineering, 5-16-1 Omiya Asahi-ku Osaka city, Japan
}

\begin{abstract}
An Al-Mg strip without center segregation could be cast using a single-roll caster equipped with a scraper at speed of $40 \mathrm{~m} / \mathrm{min}$. The scraper was useful for flattening a free solidified surface and for cooling the solidification layer by pushing the solidification layer to the roll. Clad strips consisting of 1) an Al-Mn base strip and an Al-Mg overlay strip and 2) an Al base strip and an Al-Sn-Cu overlay strip could be cast using an unequal-diameter twin-roll caster equipped with a scraper at speeds of $30 \mathrm{~m} / \mathrm{min}$ and 15 $\mathrm{m} / \mathrm{min}$, respectively. The base strip and overlay strip were strongly bonded at the interface between the base strip and the overlay strip. The elements of the overlay strip did not diffuse into the base strip. The scraper played two roles in the casting of the clad strip: prevention of the mixture of two kinds of molten metal and making the surface of the base strip a semisolid of high solid fraction.
\end{abstract}

\section{Introduction}

Al-Mg alloy strip cast using a twin-roll caster has center segregation [1]. A scraper was proposed and attached to a single-roll caster to cast Al-Mg strip without center segregation $[2,3]$. The melt drag process uses a single-roll caster to cast a strip without center segregation. However, the thickness distribution is not uniform because the free solidified surface is not flat. In the melt drag process, cooling is insufficient due to poor heat transfer between the roll and the solidification layer because the solidification layer is not pushed into the roll, and the Al-Mg strip is easily broken. As a result, $\mathrm{Al}-\mathrm{Mg}$ strip cannot be continuously cast using the conventional melt drag process. The thickness distribution and cooling of the strip can be improved by a scraper. The scraper scribes the semisolid layer on the solidification layer, and the thickness distribution and the flatness of the free solidified surface are improved. The heat transfer between the roll surface and the solidification layer becomes greater as the scraper pushes the solidification layer into the roll surface. As the result, the strip cooled enough to be cast continuously.

The scraper was attached to an unequal-diameter twin-roll caster to cast clad strip [4,5]. Two kinds of molten metals can be separated by the scraper and are not mixed. The scribed surface is a semisolid of high solid fraction. The bonding interface does not contact the oxidizing atmosphere due to the effect of the scraper. The solidification layers (two strips) are strongly bonded free from oxide film. In this manner, the scraper is very useful in the casting of both single strip and clad strip. The unequal-diameter twin-roll caster is suitable for scraper attachment and for casting of clad strip depending on the position and size of the rolls. A copper roll is used in order to increase late cooling of the strip in these casters. Therefore, the strips are rapidly solidified, and the casting speed can exceed $15 \mathrm{~m} / \mathrm{min}$.

In the present paper, a single-roll caster and a twinroll caster equipped with a scraper, as well as the properties of the single strip and the clad strip, are shown. The clad strip was cast using a vertical-type tandem twin-roll caster, and the strips cast by the two types of twin-roll casters were compared.

\section{Roll caster}

The single-roll caster equipped with a scraper and an enlarged view near the scraper are shown in Figs. 1 and 2 , respectively $[2,3]$. The scraper was made of mild steel plate and was covered by an insulator sheet of 2 $\mathrm{mm}$ in thickness. The scraper scribed the semisolid layer on the solidification layer by a small load.

Two types of twin-roll casters to cast clad strip are shown in Figs. 3. A vertical-type tandem twin-roll caster (VTTRC) is shown in Fig. 3(a), and the unequaldiameter twin-roll caster equipped with a scraper (UDTRCS) is shown in Fig. 3(b) [4-8].

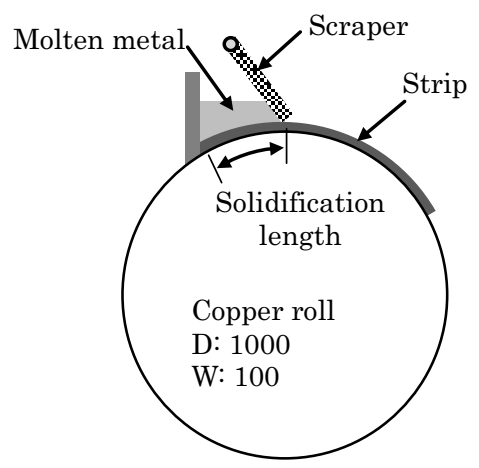

Fig. 1. Schematic illustration of a single roll caster equipped with a scraper

* Corresponding author: toshio.haga@oit.ac.jp 


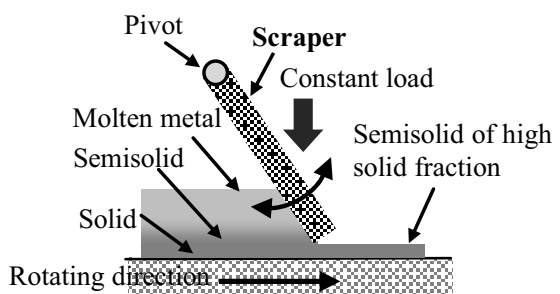

Fig. 2. Schematic illustration near the scraper

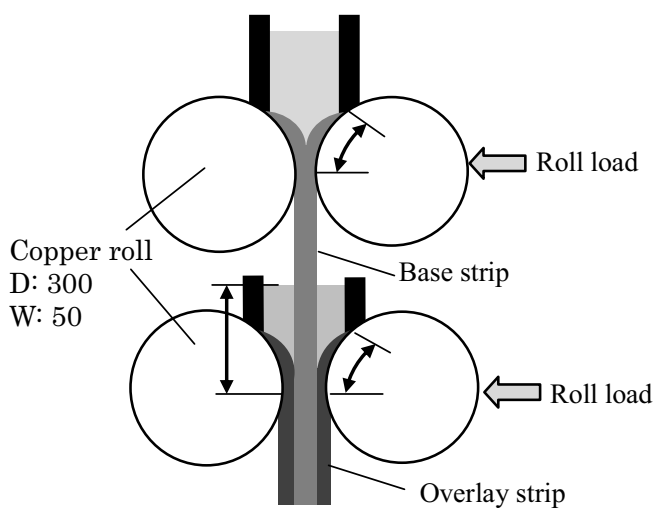

(a) Vertical type tandem twin roll caster

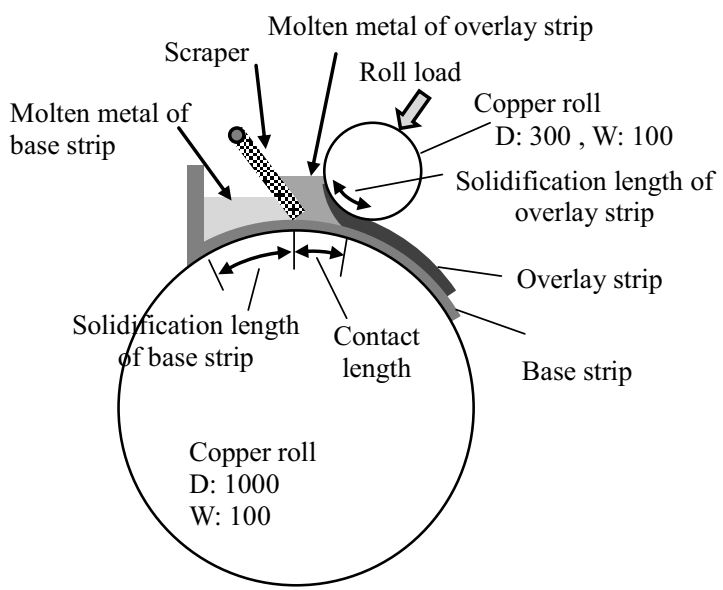

(b) Unequal diameter twin roll caster equipped with a scraper

Fig. 3. Schematic illustration of roll casters for casting clad strip

\section{Experimental conditions}

A single strip of Al-Mg alloy was cast using a single-roll caster equipped with a scraper, as shown in Fig. 1. The roll speed was $40 \mathrm{~m} / \mathrm{min}$, and the scraper load was $100 \mathrm{~N}$. The solidification length was 200 $\mathrm{mm}$. The casing temperature of the Al-Mg alloy was $705^{\circ} \mathrm{C}$. A tension test, a cup test, and microscopy of the cross section of the strip were conducted on the strip, which was cold rolled down to $1 \mathrm{~mm}$ and annealed at $380^{\circ} \mathrm{C}$ for $1.8 \mathrm{ks}$. In the cup test, the diameter of the punch was $32 \mathrm{~mm}$. The gage length and width of the test piece for the tension test were 31 $\mathrm{mm}$ and $15 \mathrm{~mm}$, respectively.

Two types of clad strips were cast. One clad strip consisted of an Al-Mg alloy overlay strip and an AlMn alloy base strip, and the other clad strip consisted of an Al-Sn-Cu alloy overlay strip and an Al base strip. The clad strip consisting of Al-Mg and Al-Mn was cast at $30 \mathrm{~m} / \mathrm{min}$ using the casters shown in Figs. 3(a) and 3(b). In Fig. 3(a), the solidification length was 60 $\mathrm{mm}$, and the contact length was $100 \mathrm{~mm}$. In Fig. 3(b), the solidification lengths of the base strip and the overlay strip were $100 \mathrm{~mm}$ and $60 \mathrm{~mm}$, respectively. The contact length was $80 \mathrm{~mm}$. The casting temperature of the $\mathrm{Al}-\mathrm{Mg}$ and $\mathrm{Al}-\mathrm{Mn}$ were $670^{\circ} \mathrm{C}$. The roll load was $5 \mathrm{kN}$, and the scraper load was $40 \mathrm{~N}$. The clad strip consisting of an overlay strip of Al-Sn$\mathrm{Cu}$ and a base strip of $\mathrm{Al}$ was cast using the caster shown in Fig. 3(b). The casting temperatures of $\mathrm{Al}$ and $\mathrm{Al}-\mathrm{Sn}-\mathrm{Cu}$ were $684^{\circ} \mathrm{C}$ and $641^{\circ} \mathrm{C}$, respectively. The solidification lengths of the base strip and the overlay strip were $190 \mathrm{~mm}$ and $170 \mathrm{~mm}$, respectively. The contact length was $80 \mathrm{~mm}$. The roll load was 5 $\mathrm{KN}$, and the scraper load was $40 \mathrm{~N}$. The roll speed was $15 \mathrm{~m} / \mathrm{min}$. A tension shear test was conducted on the clad strip of Al-Sn-Cu and Al.

The chemical compositions of the aluminum alloys are shown in Tables 1 through 4. The solidification temperatures are shown in Table 5.

Table 1. Chemical composition of Al-Mg alloy

\begin{tabular}{|l|l|l|l|l|l|l|l|}
\hline $\mathrm{Cu}$ & $\mathrm{Si}$ & $\mathrm{Mg}$ & $\mathrm{Zn}$ & $\mathrm{Fe}$ & $\mathrm{Mn}$ & $\mathrm{Ti}$ & $\mathrm{Bal}$. \\
\hline 0.00 & 0.06 & 4.81 & 0.00 & 0.07 & 0.45 & 0.03 & $\mathrm{Al}$ \\
\hline
\end{tabular}

Table 2. Chemical composition of Al-Mn alloy

\begin{tabular}{|l|l|l|l|l|l|l|l|}
\hline $\mathrm{Cu}$ & $\mathrm{Si}$ & $\mathrm{Mg}$ & $\mathrm{Zn}$ & $\mathrm{Fe}$ & $\mathrm{Mn}$ & $\mathrm{Ti}$ & $\mathrm{Bal}$. \\
\hline 0.15 & 0.28 & 0.00 & 0.01 & 0.61 & 1.24 & 0.01 & $\mathrm{Al}$ \\
\hline
\end{tabular}

Table 3. Chemical composition of $\mathrm{Al}$

\begin{tabular}{|l|l|l|l|l|l|l|l|}
\hline $\mathrm{Cu}$ & $\mathrm{Si}$ & $\mathrm{Mg}$ & $\mathrm{Zn}$ & $\mathrm{Fe}$ & $\mathrm{Mn}$ & $\mathrm{Ti}$ & $\mathrm{Bal}$. \\
\hline 0.00 & 0.04 & 0.00 & 0.01 & 0.09 & 0.00 & 0.00 & $\mathrm{Al}$ \\
\hline
\end{tabular}

Table 4. Chemical composition of Al-Sn-Cu alloy

\begin{tabular}{|c|l|l|l|l|l|l|l|}
\hline $\mathrm{Sn}$ & $\mathrm{Cu}$ & $\mathrm{Si}$ & $\mathrm{Mg}$ & $\mathrm{Zn}$ & $\mathrm{Fe}$ & $\mathrm{Mn}$ & $\mathrm{Bal}$. \\
\hline 40.40 & 0.97 & 0.01 & 0.00 & 0.00 & 0.03 & 0.00 & $\mathrm{Al}$ \\
\hline
\end{tabular}

Table 5. Solidification temperature

\begin{tabular}{|c|c|c|}
\hline Alloy & $\begin{array}{c}\text { Solidus } \\
\text { temperature }\end{array}$ & $\begin{array}{c}\text { Liquidus } \\
\text { temperature }\end{array}$ \\
\hline $\mathrm{Al}-\mathrm{Mg}$ & $577^{\circ} \mathrm{C}$ & $638^{\circ} \mathrm{C}$ \\
\hline $\mathrm{A} 1-\mathrm{Mn}$ & $643^{\circ} \mathrm{C}$ & $655^{\circ} \mathrm{C}$ \\
\hline $\mathrm{Al}$ & $650^{\circ} \mathrm{C}$ & $660^{\circ} \mathrm{C}$ \\
\hline $\mathrm{Al}-\mathrm{Sn}-\mathrm{Cu}$ & $228^{\circ} \mathrm{C}$ & $610^{\circ} \mathrm{C}$ \\
\hline
\end{tabular}

\section{Result and discussion}

\subsection{Single strip}

Al-Mg strip could be continuously cast. The surfaces of as-cast strip are shown in Fig. 4. The scribed surface had no metallic luster and was dull. A ripple 
mark existed at the roll contact surface, but not at the scribed surface. This may indicate that scribing by the scraper was steady state. No specific defect due to scribing occurred at the roll contact surface of the strip.

The cross section of as-cast Al-Mg strip cast by the single-roll caster is shown in Fig. 5. The grains near the roll contact surface were very fine. In other area, the grain size was almost uniform. Center segregation did not occur. A low degree of segregation of $\mathrm{Mg}$ occurred near the scribed surface. Cold rolling could be conducted, and the surfaces were indifferentiable after cold rolling.

The results of the tension test are presented below. In the casting direction, the tensile stress, proof stress, and elongation were $304 \mathrm{MPa}, 155 \mathrm{MPa}$, and $26.5 \%$, respectively. In the width direction, the tensile stress, proof stress, and elongation were $272 \mathrm{MPa}, 140 \mathrm{MPa}$, and $16.8 \%$, respectively. The mechanical properties of the casting direction were superior to those of the width direction.

The results of the cup test are shown in Fig. 6 . Which surface was facing outward, i.e., the scribed surface or the roll contact surface, did not affect the limiting drawing ratio (LDR), which was 2.0.

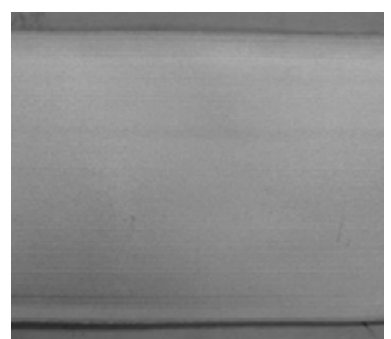

(a) Scribed surface

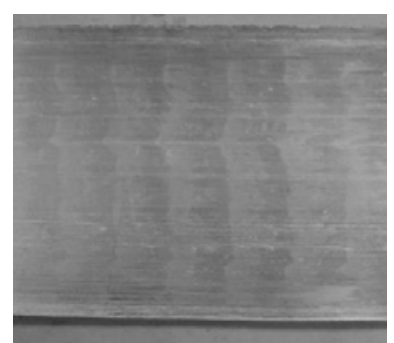

(b) Roll contact surface

Fig. 4. Surface of as-cast Al-Mg strip cast by the single roll caster shown in Fig. 1

Scribed surface

Roll contact surface

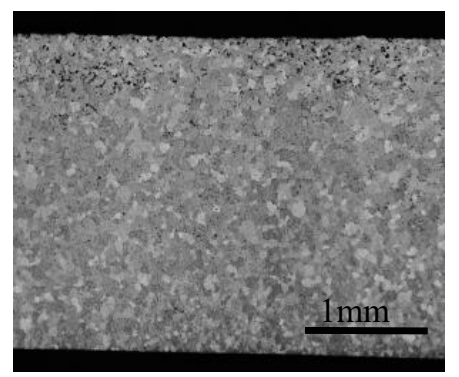

Fig. 5. Cross section of as-cast Al-Mg strip

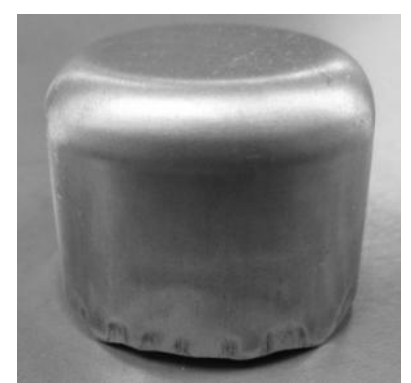

(a) Scribed surface is facing outward

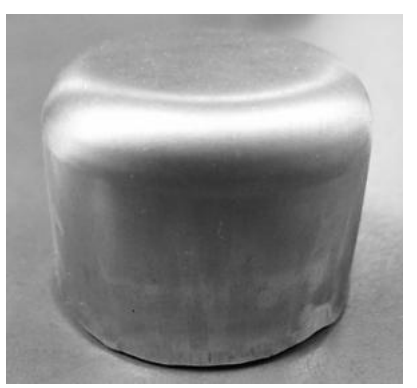

(b) Roll contact surface is facing outward
Fig. 6. Results of cup tests of Al-Mg strip

\subsection{Clad strip}

The cross sections of clad strips consisting of $\mathrm{Al}-\mathrm{Mg}$ and $\mathrm{Al}-\mathrm{Mn}$ are shown in Fig. 7. In the clad strip cast by the VTTRC, there were gaps between the $\mathrm{Al}-\mathrm{Mn}$ base strip and $\mathrm{Al}-\mathrm{Mg}$ overlay strip. On the other hand, there was no gap between the base strip and the overlay strip of the clad strip cast by the UDTRCS. The surface of the base strip was not heated to the temperature at which bonding with the overlay strip was possible in the VTTR. For example, the bonding temperature is the semisolid temperature. In the UDTRCS, the surface of the base strip is a semisolid of high solid fraction near the scraper. The surface of the base strip did not contact the oxidizing atmosphere. Therefore, the base strip is suitable for cladding. The scraper is useful for clad strip casting from two perspectives. One is that the surface of the base strip becomes a semisolid of high solid fraction. The bonding is easy, and mixture of the two types of aluminum alloy does not occur due to the effect of the high solid fraction. The other is that the surface of the base strip does not contact the oxidizing atmosphere, preventing the generation of oxide film. Clad strips consisting of various combinations of many types of aluminum alloy can be cast using the UDTRC.

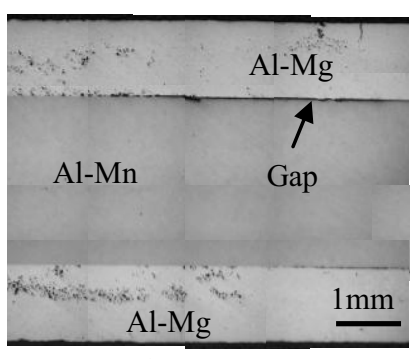

(a) Cast by VTTRC

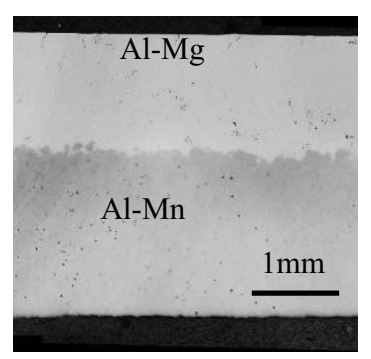

(b)Cast by UDTRCS
Fig. 7. Cross sections of clad strips

Casting of the clad strip consisting of Al-Sn-Cu and $\mathrm{Al}$ was attempted using the UDTRCS. The base strip was $\mathrm{Al}$ and the overlay strip was $\mathrm{Al}-\mathrm{Sn}-\mathrm{Cu}$. The difference in solidus lines of the base strip and the overlay strip was more than $400^{\circ} \mathrm{C}$. Some problems were predicted for casting. One was that the overlay strip of $\mathrm{Al}-\mathrm{Sn}-\mathrm{Cu}$ was not solidified by the heat from the Al base strip. If the Al-Sn-Cu solidifies, the strip thickness may become thinner. The temperature of the $\mathrm{Al}$ base strip after releasing the lower roll was higher than $500^{\circ} \mathrm{C}$. This temperature is higher than the solidus line of Al-Sn$\mathrm{Cu}$. Therefore, the Al-Sn-Cu overlay strip may re-melt. The casting of clad strip is shown in Fig. 8. The forepart of the strip in the figure is the Al base strip. The overlay strip connected to the base strip at the middle part. Meandering and warping did not occur on the base strip. 
The bonding of the overlay strip did not influence the base strip. The base strip and overlay strip were not hot rolled, because the roll load was very small. The small roll load was one reason for the non-occurrence of meandering and warping. The solidus line of the Al-Sn$\mathrm{Cu}$ overlay strip is much lower than that of the $\mathrm{Al}$ base strip. The Al-Sn-Cu overlay strip did not completely solidify when the clad strip released from the roll. Therefore, the Al base strip was subjected to heat effect by latent heat from the Al-Sn-Cu overlay strip on the conveyer. However, meandering and warping of the clad strip did not occur. The heat effect by the Al-Sn-Cu overlay strip on the Al base strip was not large enough to have a heat effect on the Al base strip. The length of the non-steady area of the forming clad strip was only 100 $\mathrm{mm}$. Re-melting and sweating did not occur at the Al$\mathrm{Mg}-\mathrm{Cu}$ overlay strip due to the heat from the $\mathrm{Al}$ base strip. Roll coating occurred. The Al-Mg-Cu overlay strip must be semisolid, but the strip did not stick to the roll.

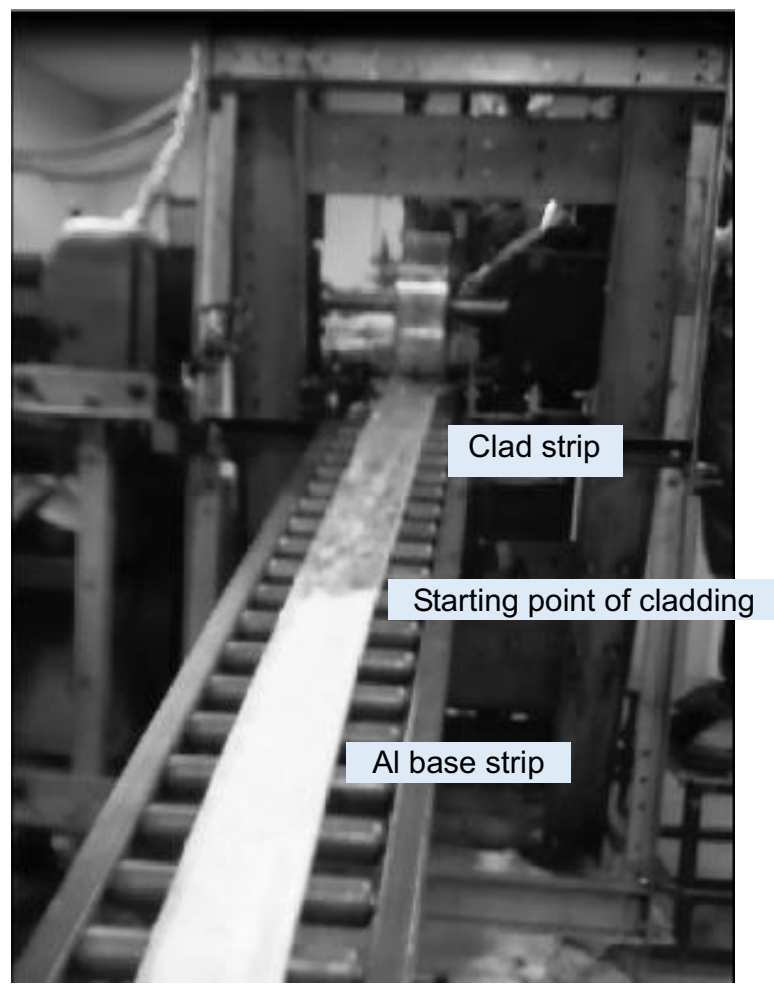

Fig. 8. Casting of clad strip in operation

The as-cast strip and the strip cold rolled down to $2 \mathrm{~mm}$ were used for the tension-shear test. The clad strip was not peeled by the cold rolling. The results of the tensionshear test are shown in Fig. 9. Breaking did not occur at the interface for either condition. This means that the two strips were strongly bonded at the interface. The roll load of the caster was very small. The two strips were not bonded by the hot rolling. The surface of Al was a semisolid of high solid fraction, which provided strong bonding. Waving of the interface was not caused by the cold rolling. The Al-Sn-Cu overlay strip did not completely solidify on the Al base strip after cooling by the roll, and the Al base strip solidified. The semisolid condition of the Al-Sn-Cu overlay strip did not influence the bonding ability.

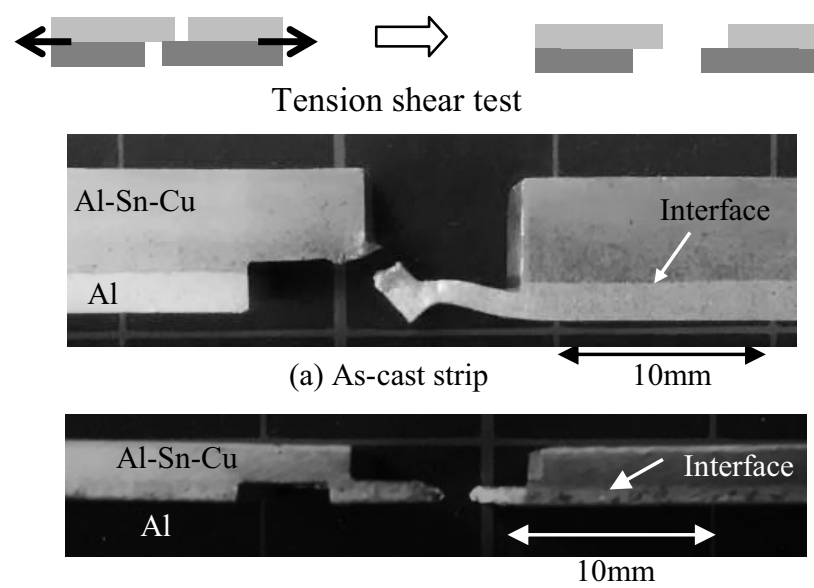

(b) Cold rolled $2 \mathrm{~mm}$-thick-strip

Fig. 9. Cross section of the clad strip after the tension shear test

The results of the line analysis of $\mathrm{Sn}$ near the interface of the as-cast strip and the cold rolled 2-mmthick strip are shown in Fig. 10.

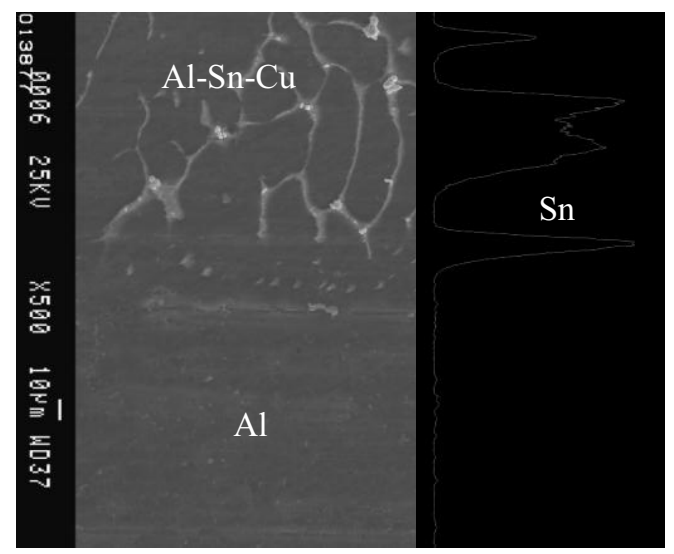

(a) Near interface of as-cast strip

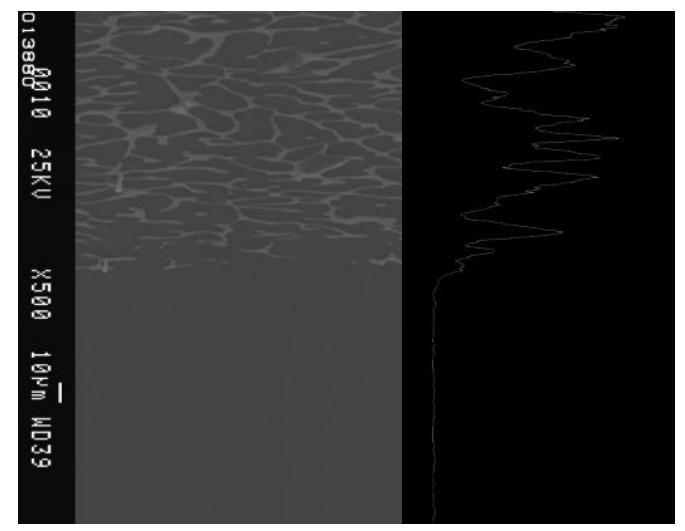

(b) Near interface of cold rolled $2 \mathrm{~mm}$-thick-strip

Fig. 10. Results of line analysis

The Sn did not diffuse into the Al base strip from the Al-Sn-Cu overlay strip. When the molten metal of the $\mathrm{Al}-\mathrm{Sn}-\mathrm{Cu}$ contacts the $\mathrm{Al}$ base strip, the surface of the Al base strip was a semisolid of high solid fraction. However, the Sn did not diffuse into the Al base strip. The casting temperature of the Al-Sn-Cu molten metal was lower than the solidus line of the Al base strip. The 
semisolid layer of the surface of the Al base strip might have been immediately solidified by the Al-Sn-Cu molten metal when contacting the $\mathrm{Al}$ base strip. Therefore, the Sn did not diffuse into the Al base strip. However, excellent bonding was attained by the semisolid metal of the Al and the molten metal of the Al$\mathrm{Sn}-\mathrm{Cu}$. The Al-Sn-Cu overlay strip was previously in semisolid condition on the Al base strip, and the Sn did not diffuse into the $\mathrm{Al}$ base strip during this time.

\section{Conclusion}

The Al-Mg strip without the center segregation could be cast at a high speed of $40 \mathrm{~m} / \mathrm{min}$ using a singleroll caster equipped with a scraper. The scraper was very useful for flattening the free solidified surface and increasing the heat transfer between the roll and the solidification layer.

An unequal-diameter twin-roll caster equipped with a scraper can cast a two-layer clad strip with a clear interface. Two clad strips consisting of 1) an Al-Mg overlay strip and an Al-Mn base strip and 2) an Al-Sn-Cu overlay strip and an Al base strip were able to be cast at high speeds of $30 \mathrm{~m} / \mathrm{min}$ and $15 \mathrm{~m} / \mathrm{min}$, respectively. In the tensile-shear test, the clad strip did not peel at the interface, but rather broke in the strip. In these clad strips, the base strip and the overlay strip were strongly bonded, and the bonding strength at the interface was stronger than that of the base strip or the overlay strip. The elements of the overlay strip did not diffuse into the base strip. The cause of the strong bonding and non-diffusion at the interface might be that the surface of the base strip was a semisolid of high solid fraction.

\section{References}

1. M. S. Kim, S. H. Kim, H. W. Kim, Scripta Materialia 152(2018)

2. T. Haga, K. Akitsu, T. Yamabayashi, S. Kumai , H. Watari, Key Engineering Materials 44(2010)

3. T. Haga , K. Akitsu , S. Kumai , H. Watari, Advanced Materials Re

4. search 445(2012)

5. T. Haga, R. Kozono, S. Nishida, H. Watari, Advances in Materials and Processing Technologies 3 (2017)

6. T. Haga, K. Okamura, S. Nishida, H. Watari, K. Matsuzaki, Materials Science Forum 879(2017)

7. T. Haga, R. Nakamura, S. Kumai, H. Watari, Archives of Materials Science and Engineering 37(2009)

8. R.Nakamura , T.Haga , H.Tsuge , S.Kumai , H.Watari, Materials Science Forum 675-677(2011)

9. T. Haga , T. Nakamura, S. Kumai, H. Watari, Applied Mechanics and Materials 52-54(2011) 